CLINICAL STUDY

\title{
Does thyroid function influence fracture risk? Prospective data from the HUNT2 study, Norway
}

\author{
Anders Svare ${ }^{1,2}$, Tom Ivar Lund Nilsen ${ }^{3}$, Bjørn Olav Åsvold ${ }^{1,4}$, Siri Forsmo ${ }^{1}$, Berit Schei ${ }^{1}$, Trine Bjøro ${ }^{5,6}$ \\ and Arnulf Langhammer ${ }^{1}$ \\ ${ }^{1}$ Department of Public Health and General Practice, Faculty of Medicine, Norwegian University of Science and Technology, N-7491 Trondheim, Norway, \\ ${ }^{2}$ Department of Medicine, Namsos Hospital, N-7800 Namsos, Norway, ${ }^{3}$ Department of Human Movement Science, Faculty of Social Sciences and \\ Technology Management, Norwegian University of Science and Technology, N-7491 Trondheim, Norway, ${ }^{4}$ Department of Endocrinology, \\ St. Olavs Hospital, Trondheim University Hospital, N-7006 Trondheim, Norway and ${ }^{5}$ Department of Medical Biochemistry, Oslo University Hospital, \\ N-0310 Oslo, Norway, ${ }^{6}$ Institute of Clinical Medicine, University of Oslo, N-O027 Oslo, Norway \\ (Correspondence should be addressed to A Svare at Department of Medicine, Namsos Hospital; Email: anders.svare@hnt.no)
}

\begin{abstract}
Objective: To prospectively study the relation between TSH and risk of hip and forearm fractures. Design: A population-based cohort study.

Methods: In a substudy of the second survey of the Nord Trøndelag Health Study, Norway (HUNT2, 1995-97), linked with a hospital-based fracture registry, we investigated the relation between baseline TSH and risk of hip and/or forearm fractures.

Population: A total of 16610 women and 8595 men aged 40 years or more, without previous self-reported thyroid disease and hip or forearm fractures.

Results: During 12.5 years follow-up, a total of 1870 women and 342 men experienced hip or forearm fractures. Overall, there was no relation between baseline TSH and fracture risk. However, there was weak evidence that women with TSH $<0.5$ and $>3.5 \mathrm{mU} / \mathrm{l}$ had a slightly increased risk of hip fractures (hazard ratio (HR) 1.30, 95\% CI 0.97-1.94 and HR 1.19, 95\% CI 0.93-1.52) compared with the reference group with TSH of 1.5-2.4 mU/l. Supplementary analyses showed higher hip fracture risk in women with TSH $>4.0 \mathrm{mU} / \mathrm{l}$ and negative thyroid peroxidase antibodies (TPOAb) compared with the reference group (HR 1.75, 95\% CI 1.24-2.46).

Conclusion: We found no statistically significant relation between baseline TSH and subsequent fracture risk, but the data suggest a weak positive association with hip fracture risk among women with both low and high TSH. The latter association was confined to women with negative TPOAb status.
\end{abstract}

European Journal of Endocrinology 169 845-852

\section{Introduction}

Thyroid dysfunction is prevalent, affects more women than men, and the incidence increases with age (1). In the Norwegian HUNT2 study, the prevalence of formerly diagnosed hypothyroidism was $4.8 \%$ in females and $0.9 \%$ in males, whereas $2.5 \%$ of women and $0.6 \%$ of men had formerly diagnosed hyperthyroidism (1). Mainly through effects on nuclear receptors, but also through non-genomic mechanisms, thyroid hormones affect every organ system in the human body (2). Overt thyroid dysfunction has especially unfavorable effects on the musculoskeletal, circulatory and nervous organ systems (2). Similar but weaker influences have been reported in subclinical thyroid dysfunction (3).

Thyroid dysfunction could seemingly influence fracture risk by increasing the risk of falling or by weakening the bone strength. Hypothyroidism is a risk factor for falls in elderly individuals (4), and hyperthyroidism has for more than a century been known as a risk factor for osteoporosis (5). Both overt hypothyroidism and hyperthyroidism have been associated with increased risk of fractures in previous studies $(6,7$, $8,9,10,11,12,13,14)$. Other studies have reported that fractures are more common in persons with subclinical thyroid dysfunction (15, 16), and some have found fracture incidence to increase by decreasing thyroid-stimulating hormone (TSH) within the reference range $(13,17,18)$. However, the results of these and other studies are inconsistent $(7,13,14,19,20)$. A few studies have investigated the importance of autoimmunity in thyroid disorders for fracture risk, but the results are inconclusive $(21,22)$. Hence, the effect of thyroid function on fracture risk is not clear.

In this prospective population-based study of more than 25000 individuals, we have examined whether thyroid function measured as serum TSH was associated with the risk of subsequent hip and/or forearm fractures. 


\section{Subjects and methods}

\section{Subjects}

Between 1995 and 1997, all inhabitants in the NorthTrøndelag County in Norway, aged 20 years or older, were invited to the second wave of the Nord-Trøndelag Health Study (HUNT2) (23). A total of 65237 persons (69.5\% of the invited) participated. The participants filled in questionnaires on a range of lifestyle and health-related topics. They also underwent a clinical examination that included anthropometric measures, and a non-fasting blood sample was drawn. TSH was measured in all women aged 40 years or older and in a $50 \%$ random sample of men of similar age (1). Based on the questionnaire information, we excluded 2855 persons with previous or current thyroid diseases (hypothyroidism, hyperthyroidism, goitre or other thyroid diseases) or related treatment (levothyroxine, carbimazole, thyroid surgery or radioiodine therapy). We also excluded 4395 persons who reported previous hip and forearm fractures or were registered with a fracture before baseline. In addition, 429 persons were excluded due to incomplete information on smoking status and BMI. This left a total of 16610 women and 8595 men for the statistical analyses (Fig. 1).

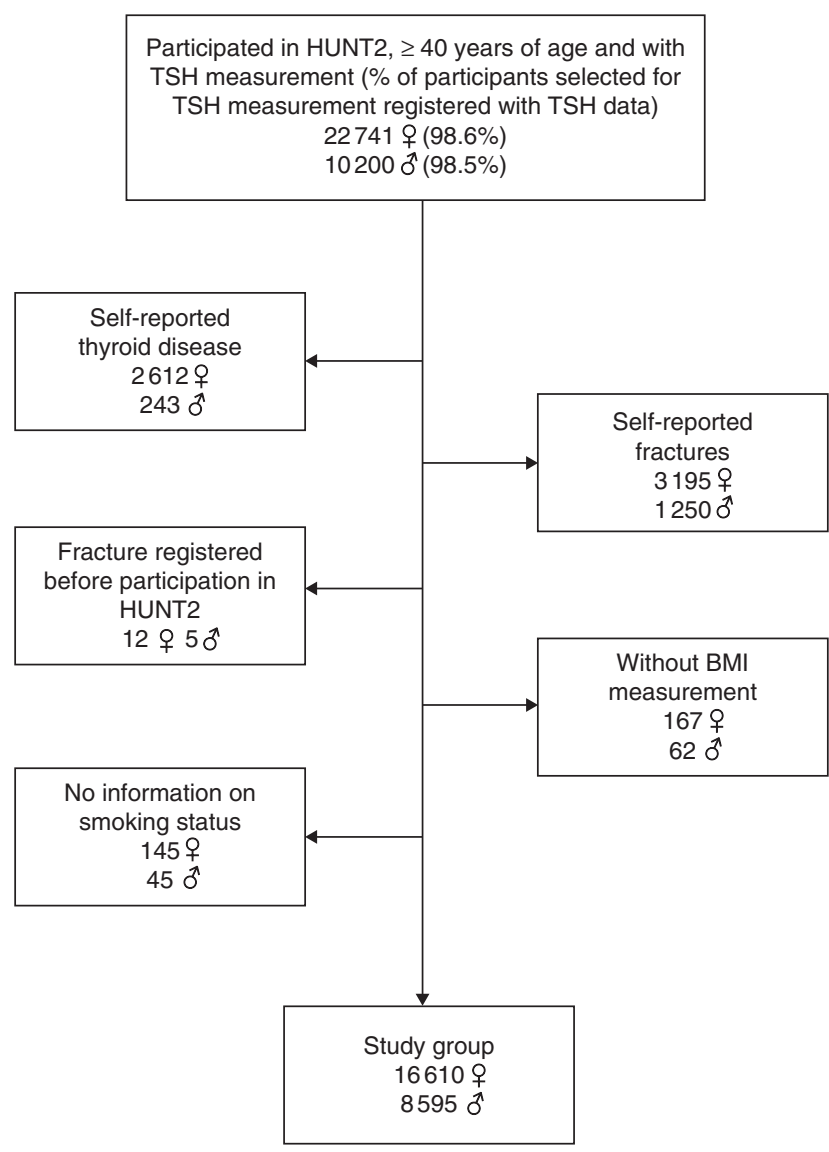

Figure 1 Development of the study group.

\section{Thyroid function tests}

Serum TSH was measured in blood samples drawn at any time of the day and analyzed by DELFIA hTSH Ultra (Wallac Oy, Turku, Finland) at the Hormone Laboratory, Aker University Hospital, Oslo, Norway. The assay had a sensitivity of $0.03 \mathrm{mU} / \mathrm{l}$ and total analytic variation $<5 \%$. Based on previously reported data from HUNT2, the reference range for TSH in this study was $0.5-3.5 \mathrm{mU} / \mathrm{l}$ (1). We grouped the participants into five categories based on TSH level: three categories within the reference range $(0.5-1.4,1.5-2.4$ and $2.5-3.5 \mathrm{mU} / \mathrm{l})$, one category below $(<0.5 \mathrm{mU} / \mathrm{l})$, and one category above the reference range $(>3.5 \mathrm{mU} / \mathrm{l})$. The $1.5-2.4 \mathrm{mU} / \mathrm{l}$ category was used as reference in order to reduce the number of individuals with incipient hyperthyroidism in the reference category.

If TSH $<0.20 \mathrm{mU} / \mathrm{l}$, free thyroxine $\left(\mathrm{FT}_{4}\right)$ and total triiodothyronine $\left(\mathrm{T}_{3}\right)$ were measured, and if TSH $>4.0 \mathrm{mU} / \mathrm{l}, \mathrm{FT}_{4}$ and thyroid peroxidase antibodies (TPOAb) were measured. $\mathrm{FT}_{4}$ was measured by DELFIA $\mathrm{FT}_{4}$ (total analytical variation $<7 \%$, reference range 8-20 pmol/l), $\mathrm{T}_{3}$ by AutoDELFIA $\mathrm{T}_{3}$ (total analytical variation $<7 \%$, reference range $1.2-2.7 \mathrm{nmol} / \mathrm{l}$ ) and TPOAb by luminoimmunoassay from B.R.A.H.M.S. Diagnostica $\mathrm{GmbH}$, Berlin, Germany (reference range $<200 \mathrm{U} / \mathrm{ml}$ ). We classified hyperthyroidism as overt if TSH was $<0.20 \mathrm{mU} / \mathrm{l}$ and $\mathrm{FT}_{4}$ or $\mathrm{T}_{3}$ above the reference range, and hypothyroidism as overt if TSH was above $4.0 \mathrm{mU} / \mathrm{l}$ and $\mathrm{FT}_{4}$ below the reference range.

After HUNT2, subjects with TSH $<0.20 \mathrm{mU} / \mathrm{l}$ or above $5.0 \mathrm{mU} / \mathrm{l}$, or TSH above $4.0 \mathrm{mU} / \mathrm{l}$ with low $\mathrm{FT}_{4}$ or elevated TPOAb levels were informed by letter and recommended to consult their general practitioner (GP) for follow-up.

\section{Follow-up and fracture recording}

Information on death and emigration from the county was obtained from the National Population Register. Person-years were calculated from the date of participation in HUNT2 until the date of fracture, death, emigration from the county, or end of follow-up (31st December 2008), whichever occurred first.

From the Patient Administration System (PAS) at the two hospitals in North-Trøndelag County (Namsos Hospital and Levanger Hospital), we identified i) all treated forearm and hip fractures and ii) all clinical controls of such fractures between 15th August 1995 and 31st December 2008. Virtually all fractures in North-Trøndelag County are treated at these two hospitals. For patients with a fracture diagnosis or fracture-related procedure code in PAS, the fracture diagnosis was retrospectively validated by specially trained medical doctors, health secretaries and nurses by evaluating the patients' medical records. Until 1st January 1999, the hospitals utilised ICD-9 and the third version of the national classification of surgical 
procedures (SIFF-95). We searched for ICD-9 codes 824 (hip fractures) and 813 (forearm fractures), and SIFF-95 hip fracture procedure codes 8072, 8073, 8079, 8103, $8106,8332,8334,8336$ and 8339 and forearm fracture procedure codes 8063, 8065, 8066, 8075, 8078, 8101-8105 and 8109. From 1st January 1999, ICD-10 and the Nomesco Classification of Surgical Procedures (NCSP, a common Nordic classification system) were used. We searched for ICD-10 codes S72.0-S72.2 and S72.9 (hip fractures) and S52.0-S52.9 (forearm fractures), and NCSP hip fracture procedure codes NFB 00-03, 09-13, 19-20, 30, 40, 59, 99, NFJ 00-03, 10-13, 20-23, 30-33, 40-43, 50-55, 60-63, 70-73, 80-83, 90-93 and TNF40 and forearm fracture procedure codes NCJ 00-99, NCU 39, 49 and TNC 31-34, 39.

Until 31st December 2002, we also had information about fractures from X-ray evaluations at the two hospitals. As this information was not available during the whole follow-up period, these additional data were merely used in sensitivity analyses. At the radiology departments at the hospitals, the X-ray pictures and their evaluations were classified and stored according to the region they depicted. All X-ray evaluations from the regions of interest were checked, and whenever they indicated a fracture, this was validated in the person's medical record. Until 31st December 2002, there were 1148 fractures registered from either PAS or X-ray descriptions, of which $110(9.6 \%)$ were registered in PAS only, as well as $110(9.6 \%)$ that were registered in X-ray descriptions only.

All ulnar and radial forearm fractures and all hip fractures including the subtrochanteric area were included. Pathological and avulsion fractures were excluded. We had no information on fracture mechanisms (low-energy or high-energy fractures). Because (forearm) bone mineral density (BMD) was only measured in selected subgroups in HUNT2, we did not include BMD data in our analyses.

\section{Statistical analyses}

The analyses were performed on forearm and hip fractures separately and combined. When combined fractures were studied, the first fracture (hip or forearm) was counted as an event. When the sites were studied separately, the first site-specific fracture was the event (e.g. when studying hip fractures, subjects were not censored due to a forearm fracture). All main analyses are based on fracture data obtained from PAS and verified in the medical records.

We used Cox proportional hazard model to estimate adjusted hazard ratio (HR) for fractures by baseline TSH included as continuous variable within the reference range, as well as in the five categories.

Many participants with thyroid dysfunction were probably treated shortly after the survey. As a large Danish population-based case-control study found an increased fracture risk within 5 years after the diagnosis of hyperthyroidism (12), we performed a sub-analysis where follow-up was restricted to 31st December 2002. In other sub-analyses, we investigated i) whether there was any difference in fracture risk in participants with overt hypothyroidism or hyperthyroidism compared with euthyroid subjects and ii) whether fracture risk differed depending on TPOAb status (negative/positive) among participants with TSH $>4 \mathrm{mU} / \mathrm{l}$.

All associations were adjusted for age (10-year categories), BMI (gender-specific quintiles, $\mathrm{kg} / \mathrm{m}^{2}$ ) and smoking status (never, former, current). In supplementary analyses, we also assessed potential confounding by self-esteemed health status, health problems limiting leisure activities, recreational physical activity, postmenopausal use of systemic oestrogens and menopausal status (age at menopause was set to 51 years if no information was available). However, adjustment for these additional variables had minimal effect on the estimates, and they were not included in the final analyses.

All analyses were stratified by gender. Violation of the proportional hazard assumption was assessed by visual inspection of log-log plots.

Precision of the estimated associations was assessed by a $95 \%$ CI. All statistical tests were two-sided, and all analyses were conducted using SPSS version 18.0.

\section{Ethics}

The study was approved by the Regional Committee for Medical and Health Research Ethics, the Norwegian Data Inspectorate, and the Norwegian Directorate of Health. All participants gave their informed consent.

\section{Results}

Among 16610 women, 1870 (11.3\%) had a first hip or forearm fracture, $778(4.7 \%)$ had a first hip fracture and $1192(7.2 \%)$ a first forearm fracture. Among 8595 men, $342(4.0 \%)$ had a first hip or forearm fracture, $228(2.7 \%)$ a first hip fracture and $124(1.4 \%)$ a first forearm fracture. The median follow-up time was 12.5 years, and the median age for the first hip fracture was 81 years (inter quartile range (IQR) 75- 86) for both genders, whereas the median age for forearm fractures was 68 (IQR 58-77) years in women and 65 (IQR 56-76) years in men. The baseline characteristics of the study group are given in Tables 1 (women) and 2 (men). No violations of the proportional hazard assumption were observed.

We did not find any clear association between TSH and fracture risk in hip and/or forearm in the adjusted analyses (Tables 3, 4 and 5). However, there was weak evidence that women with TSH $<0.5$ and $>3.5 \mathrm{mU} / \mathrm{l}$ had a slightly increased risk of hip fractures (HR 1.30, 95\% CI $0.97-1.94$ and HR 1.19, 95\% CI 0.93-1.52) 
Table 1 Baseline characteristics of the female study population by TSH categories.

\begin{tabular}{|c|c|c|c|c|c|c|}
\hline & \multicolumn{5}{|c|}{ TSH (mU/l) } & \multirow[b]{2}{*}{$P$ value } \\
\hline & $<0.50$ & $0.50-1.4$ & $1.5-2.4$ & $2.5-3.5$ & $>3.5$ & \\
\hline Participants $(n)$ & 408 & 6749 & 6004 & 2071 & 1378 & \\
\hline Baseline age $^{a}$ (years) (IQR) & $57(48-70)$ & $53(46-65)$ & $56(48-68)$ & $58(49-71)$ & $61(50-72)$ & $<0.001$ \\
\hline $\mathrm{BMI}^{\mathrm{b}}\left(\mathrm{kg} / \mathrm{m}^{2}\right)$ (S.D.) & $26.4(4.7)$ & $26.3(4.3)$ & $27.1(4.6)$ & $27.4(4.7)$ & $27.6(4.7)$ & $<0.001$ \\
\hline $\mathrm{TSH}^{\mathrm{a}}(\mathrm{mU} / \mathrm{l})(\mathrm{IQR})$ & $0.34(0.15-0.43)$ & $1.1(0.9-1.3)$ & $1.9(1.6-2.1)$ & $2.8(2.6-3.1)$ & $4.6(3.9-6.2)$ & \\
\hline Smoking status & & & & & & $<0.001$ \\
\hline Never (\%) & $170(41.7)$ & $2879(42.7)$ & $3227(53.7)$ & $1243(60.0)$ & $845(61.3)$ & \\
\hline Former (\%) & $72(17.6)$ & $1373(20.3)$ & $1286(21.4)$ & $443(21.4)$ & $301(21.8)$ & \\
\hline Current (\%) & $166(40.7)$ & 2497 (37.0) & $1491(24.8)$ & $385(18.6)$ & $232(16.8)$ & \\
\hline Post-menopausal $^{\mathrm{c}}(\%)$ & $288(70.6)$ & $4049(60.0)$ & $3968(66.1)$ & $1446(69.8)$ & $1022(74.2)$ & $<0.001$ \\
\hline Ever systemic oestrogen users (\%) & $58(14.2)$ & $1142(16.9)$ & $1052(17.5)$ & $331(16.0)$ & $205(14.9)$ & 0.042 \\
\hline Recreational physical activity ${ }^{\mathrm{d}}$ & & & & & & $<0.001$ \\
\hline Little (\%) & $254(62.3)$ & $4234(62.7)$ & $3989(61.4)$ & $1271(61.4)$ & $803(58.3)$ & \\
\hline Much (\%) & $71(17.4)$ & $1568(23.1)$ & $1339(22.3)$ & $455(22.0)$ & $293(21.3)$ & \\
\hline Subjective health status ${ }^{d}$ & & & & & & 0.034 \\
\hline $\operatorname{Bad}(\%)$ & $161(39.5)$ & 2286 (33.9) & $2041(34.0)$ & $723(34.9)$ & $443(31.1)$ & \\
\hline Good (\%) & $240(58.8)$ & $4395(65.1)$ & $3904(65.0)$ & $1322(63.8)$ & $924(67.1)$ & \\
\hline
\end{tabular}

IQR, interquartile range; TSH, thyroid-stimulating hormone.

a'Median.

${ }^{\mathrm{b}}$ Mean.

${ }^{\mathrm{C}}$ If no age at menopause was recorded, the menopausal age was set at 51 years.

${ }^{d}$ Some participants had missing information on this variable. The proportion with missing information can be calculated from the absolute percentages in brackets.

compared with the reference group with TSH of 1.5-2.4 mU/l (Table 4).

In additional analyses we assessed the linear relation between TSH and risk of fractures, using TSH within the reference range as a continuous variable in the regression model. For each mU/l increase in TSH, the combined fracture HR was 0.96 (95\% CI $0.89-1.03)$ in women and $0.90(95 \%$ CI $0.76-1.06)$ in men. These associations were largely similar when forearm and hip fractures were studied separately (data not shown).
Among the 946 women with TSH $>4.0 \mathrm{mU} / \mathrm{l}$ and TPOAb data (negative/positive), the HR for hip fractures in TPOAb-negative women was 1.87 (95\% CI 1.11-3.16) compared with TPOAb-positivewomen, and 1.75 (95\% CI 1.24-2.46) compared with women with TSH in the reference group $(1.5-2.4 \mathrm{mU} / \mathrm{l})$.

There were 16 fractures in 154 participants with overt hypothyroidism and ten fractures in 58 with overt hyperthyroidism. The fracture risk was not statistically

Table 2 Baseline characteristics of the male study population by TSH categories.

\begin{tabular}{|c|c|c|c|c|c|c|}
\hline & \multicolumn{5}{|c|}{ TSH (mU/l) } & \multirow[b]{2}{*}{$P$ value } \\
\hline & $<0.50$ & $0.50-1.4$ & $1.5-2.4$ & $2.5-3.5$ & $>3.5$ & \\
\hline Participants $(n)$ & 150 & 3706 & 3258 & 982 & 499 & \\
\hline Baseline age $^{\mathrm{a}}$ (years) (IQR) & $55(48-70)$ & $55(48-67)$ & $57(49-69)$ & $62(51-72)$ & $66(54-75)$ & $<0.001$ \\
\hline $\mathrm{BMI}^{\mathrm{b}}\left(\mathrm{kg} / \mathrm{m}^{2}\right)$ (S.D.) & $26.4(3.5)$ & $26.5(3.3)$ & $27.0(3.5)$ & $27.4(3.7)$ & $27.4(3.7)$ & $<0.001$ \\
\hline $\mathrm{TSH}^{\mathrm{a}}(\mathrm{mU} / \mathrm{l})(\mathrm{IQR})$ & $0.38(0.30-0.46)$ & $1.1(0.9-1.3)$ & $1.8(1.6-2.1)$ & $2.9(2.6-3.1)$ & $4.5(3.9-5.8)$ & \\
\hline Smoking status & & & & & & $<0.001$ \\
\hline Never (\%) & 35 (23.2) & $992(26.8)$ & $1109(34.0)$ & $334(34.0)$ & $195(39.1)$ & \\
\hline Former (\%) & $60(38.7)$ & $1364(36.8)$ & $1286(39.5)$ & 459 (46.7) & 228 (46.8) & \\
\hline Current (\%) & 55 (36.9) & $1350(36.4)$ & $863(26.5)$ & 189 (19.2) & $76(14.9)$ & \\
\hline Recreational physical activity ${ }^{\mathrm{c}}$ & & & & & & 0.002 \\
\hline Little (\%) & $82(54.7)$ & $2127(57.4)$ & 1854 (56.9) & $561(57.1)$ & $275(55.1)$ & \\
\hline Hard (\%) & $46(30.7)$ & $1201(32.4)$ & 1049 (32.2) & 291 (29.6) & $139(27.9)$ & \\
\hline $\begin{array}{l}\text { Subjective health } \\
\text { status }^{\mathrm{C}}\end{array}$ & & & & & & 0.351 \\
\hline Bad (\%) & $53(35.3)$ & $1126(30.4)$ & $971(29.8)$ & $305(31.1)$ & $166(33.3)$ & \\
\hline Good (\%) & $96(64.0)$ & $2560(69.1)$ & $2270(69.7)$ & $669(68.1)$ & $331(66.3)$ & \\
\hline
\end{tabular}

IQR, interquartile range; TSH, thyroid-stimulating hormone.

aMedian.

${ }^{\mathrm{b}}$ Mean.

${ }^{\mathrm{c}}$ Some participants had missing information on this variable. The proportion with missing information can be calculated from the absolute percentages in brackets. 
Table 3 Hazard ratios for fractures ${ }^{a}$ between categories of baseline TSH.

\begin{tabular}{|c|c|c|c|c|}
\hline $\begin{array}{l}\text { TSH } \\
(\mathrm{mU} / \mathrm{l})\end{array}$ & $\begin{array}{l}\text { Partici- } \\
\text { pants } \\
(n)\end{array}$ & $\begin{array}{l}\text { Fractures } \\
(n)\end{array}$ & $\begin{array}{l}\text { Hazard ratio } \\
(95 \% \mathrm{Cl})\end{array}$ & $\begin{array}{c}\text { Adjusted }^{\mathrm{b}} \\
\text { hazard ratio } \\
(95 \% \mathrm{Cl})\end{array}$ \\
\hline \multicolumn{5}{|l|}{ Women } \\
\hline & 408 & 54 & $1.26(0.96-1.67)$ & $\begin{array}{l}1.14 \\
\quad(0.86-1.51)\end{array}$ \\
\hline $0.5-1.4$ & 6749 & 816 & $0.96(0.86-1.06)$ & $\begin{array}{l}1.03 \\
\quad(0.92-1.14)\end{array}$ \\
\hline $1.5-2.4$ & 6004 & 614 & 1.00 (reference) & $\begin{array}{l}1.00 \\
\text { (reference) }\end{array}$ \\
\hline $2.5-3.5$ & 2071 & 205 & $1.07(0.92-1.24)$ & $\begin{array}{l}0.98 \\
\quad(0.84-1.13)\end{array}$ \\
\hline$>3.5$ & 1378 & 181 & $1.23(1.04-1.45)$ & $\begin{array}{l}1.10 \\
\quad(0.93-1.29)\end{array}$ \\
\hline \multicolumn{5}{|l|}{ Men } \\
\hline & 150 & 6 & $0.95(0.42-2.15)$ & $\begin{array}{l}0.84 \\
\quad(0.37-1.90)\end{array}$ \\
\hline $0.5-1.4$ & 3706 & 159 & $0.78(0.61-0.98)$ & $\begin{array}{l}0.83 \\
\quad(0.65-1.05)\end{array}$ \\
\hline $1.5-2.4$ & 3258 & 125 & 1.00 (reference) & $\begin{array}{l}1.00 \\
\quad \text { (reference) }\end{array}$ \\
\hline $2.5-3.5$ & 982 & 29 & $0.88(0.61-1.26)$ & $\begin{array}{l}0.70 \\
\quad(0.49-1.01)\end{array}$ \\
\hline$>3.5$ & 499 & 23 & $1.12(0.72-1.73)$ & $\begin{array}{l}0.72 \\
\quad(0.46-1.13)\end{array}$ \\
\hline
\end{tabular}

${ }^{\mathrm{a}}$ Forearm and hip fractures combined.

${ }^{\mathrm{b}}$ Adjusted for baseline age, BMI and smoking status.

significantly different from the risk among euthyroid participants (data not shown).

Results from supplementary analyses restricted to follow-up until 31st of December 2002 remained largely similar, indicating little bias by treatment of thyroid dysfunction initiated after baseline. We performed three additional sensitivity analyses: i) the analyses were performed using all fractures, registered either by PAS or from X-ray evaluations; ii) the analyses were restricted to individuals $\geq 65$ years of age; and iii) the analyses were done without BMI as a covariable. However, the results were in principle the same as in the main analyses (data not shown).

\section{Discussion}

In this large population-based prospective study, we did not find any clear relation between baseline TSH and subsequent risk of forearm fracture. There was some weak evidence of increased risk of hip fracture in women with TSH $<0.5$ and $>3.5 \mathrm{mU} / \mathrm{l}$. Among persons who had their TPOAb measured, i.e. the participants with TSH $>4.0 \mathrm{mlU} / \mathrm{l}$, the hip fracture risk was higher in TPOAb-negative than in TPOAb-positive women.

This is one of the largest population-based prospective studies on the relation between thyroid function and fracture risk. We included men in our study, whereas many similar studies exclusively report female data. The registration of incident fractures at both hospitals in the county should ensure minor loss to follow-up.
Our study has some limitations. Blood samples were drawn at any time of the day, and we had no information on factors (e.g. vigorous physical activity, shift work, acute diseases) known to influence thyroid function (24). A pathological TSH will often normalise spontaneously, but we measured TSH only once $(25,26)$. Further thyroid data $\left(\mathrm{FT}_{4}, \mathrm{~T}_{3}, \mathrm{TPOAb}\right.$ and TSH receptor antibodies (TRAb)) on all participants would have enabled a better classification of the study population. We were not able to distinguish between low- and high-energy fractures. A low BMD is likely less important in high-energy fractures. A recent study from Southern Norway has classified 5\% of distal radius fractures in women and 29\% in men above 49 years of age as high-energy fractures (27). All these limitations may potentially weaken the associations.

We only had X-ray verification of fractures until 2003, but a sensitivity analysis utilising fracture data from X-ray descriptions did not change the estimates. As the effect of thyroid function on BMD may, at least partly, be mediated through BMI, the role of BMI as a confounder could be questioned (28). However, exclusion of BMI from the models did not change the estimates. Moreover, the absolute number of participants with overt hypo- and hyperthyroidism was small, reducing the power to detect differences between these groups and euthyroid subjects. We had no information on vertebral fractures and could therefore not examine whether thyroid dysfunction may be associated with increased risk of such fractures, as suggested by some studies $(7,17)$.

Table 4 Hazard ratios for hip fractures between TSH categories.

\begin{tabular}{|c|c|c|c|c|}
\hline $\begin{array}{l}\text { TSH } \\
(\mathrm{mU} / \mathrm{l})\end{array}$ & $\begin{array}{l}\text { Partici- } \\
\text { pants } \\
(n)\end{array}$ & $\begin{array}{l}\text { Fractures } \\
\qquad(n)\end{array}$ & $\begin{array}{l}\text { Hazard ratio } \\
\qquad(95 \% \mathrm{Cl})\end{array}$ & $\begin{array}{c}\text { Adjusted }^{\mathrm{a}} \\
\text { hazard ratio } \\
(95 \% \mathrm{Cl})\end{array}$ \\
\hline \multicolumn{5}{|l|}{ Women } \\
\hline$<0.5$ & 408 & 26 & $1.53(1.02-2.29)$ & $\begin{array}{l}1.30 \\
\quad(0.87-1.94)\end{array}$ \\
\hline $0.5-1.4$ & 6749 & 290 & $0.96(0.81-1.13)$ & $\begin{array}{l}1.10 \\
(0.93-1.29)\end{array}$ \\
\hline $1.5-2.4$ & 6004 & 267 & 1.00 (reference) & $\begin{array}{l}1.00 \\
\quad \text { (reference) }\end{array}$ \\
\hline $2.5-3.5$ & 2071 & 112 & $1.24(0.99-1.54)$ & $\begin{array}{l}1.05 \\
\quad(0.84-1.31)\end{array}$ \\
\hline$>3.5$ & 1378 & 83 & $1.41(1.10-1.80)$ & $\begin{array}{l}1.19 \\
\quad(0.93-1.52)\end{array}$ \\
\hline \multicolumn{5}{|l|}{ Men } \\
\hline$<0.5$ & 150 & 5 & $1.17(0.48-2.86)$ & $\begin{array}{l}0.99 \\
\quad(0.40-2.43)\end{array}$ \\
\hline $0.5-1.4$ & 3706 & 84 & $0.73(0.55-0.98)$ & $\begin{array}{l}0.80 \\
\quad(0.59-1.07)\end{array}$ \\
\hline $1.5-2.4$ & 3258 & 99 & 1.00 (reference) & $\begin{array}{l}1.00 \\
\quad \text { (reference) }\end{array}$ \\
\hline $2.5-3.5$ & 982 & 24 & $0.84(0.54-1.31)$ & $\begin{array}{l}0.63 \\
\quad(0.40-0.98)\end{array}$ \\
\hline$>3.5$ & 499 & 16 & $1.15(0.68-1.94)$ & $\begin{array}{l}0.64 \\
\quad(0.37-1.09)\end{array}$ \\
\hline
\end{tabular}

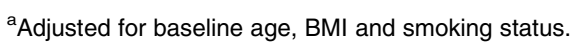


Table 5 Hazard ratios for forearm fractures between TSH categories.

\begin{tabular}{|c|c|c|c|c|}
\hline $\begin{array}{l}\text { TSH } \\
(\mathrm{mU} / \mathrm{l})\end{array}$ & $\begin{array}{l}\text { Partici- } \\
\text { pants } \\
(n)\end{array}$ & $\begin{array}{c}\text { Fractures } \\
(n)\end{array}$ & $\begin{array}{l}\text { Hazard ratio } \\
(95 \% \mathrm{Cl})\end{array}$ & $\begin{array}{c}\text { Adjusted }^{\text {a }} \\
\text { hazard ratio } \\
(95 \% \mathrm{Cl})\end{array}$ \\
\hline \multicolumn{5}{|l|}{ Women } \\
\hline$<0.5$ & 408 & 31 & $1.12(0.78-1.62)$ & $\begin{array}{l}1.08 \\
\quad(0.75-1.56)\end{array}$ \\
\hline $0.5-1.4$ & 6749 & 478 & $0.98(0.86-1.12)$ & $\begin{array}{l}1.02 \\
\quad(0.90-1.17)\end{array}$ \\
\hline $1.5-2.4$ & 6004 & 429 & 1.00 (reference) & $\begin{array}{l}1.00 \\
\quad \text { (reference) }\end{array}$ \\
\hline $2.5-3.5$ & 2071 & 141 & $0.96(0.79-1.16)$ & $\begin{array}{l}0.92 \\
\quad(0.76-1.11)\end{array}$ \\
\hline$>3.5$ & 1378 & 113 & $1.19(0.97-1.46)$ & $\begin{array}{l}1.11 \\
\quad(0.90-1.37)\end{array}$ \\
\hline \multicolumn{5}{|l|}{ Men } \\
\hline$<0.5$ & 150 & 1 & $0.47(0.06-3.38)$ & $\begin{array}{l}0.47 \\
\quad(0.07-3.41)\end{array}$ \\
\hline $0.5-1.4$ & 3706 & 52 & $0.92(0.62-1.36)$ & $\begin{array}{l}0.96 \\
\quad(0.65-1.42)\end{array}$ \\
\hline $1.5-2.4$ & 3258 & 49 & 1.00 (reference) & $\begin{array}{l}1.00 \\
\quad \text { (reference) }\end{array}$ \\
\hline $2.5-3.5$ & 982 & 15 & $1.05(0.59-1.87)$ & $\begin{array}{l}1.00 \\
\quad(0.56-1.78)\end{array}$ \\
\hline$>3.5$ & 499 & 7 & $0.99(0.45-2.19)$ & $\begin{array}{l}0.89 \\
\quad(0.40-1.98)\end{array}$ \\
\hline
\end{tabular}

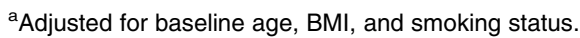

Thyroid function could influence fracture risk both by increased risk of falls and by reduced BMD. Hypothyroidism is a risk factor for falls (4), and hyperthyroidism is a risk factor for osteopenia and osteoporosis $(29,30)$. A cross-sectional study in this cohort found a lower BMD among participants with TSH $<0.5 \mathrm{mU} / \mathrm{l}$, but did not show any relation between TSH and BMD above this TSH level (31). However, some studies report a positive relation between TSH in the normal range and BMD $(32,33,34)$, and there have even been studies that report an association between elevated TSH and low $\operatorname{BMD}(35,36)$.

Although several studies have investigated the relation between thyroid function and fracture risk, they differ on fracture site(s) under study and the way of assessing thyroid status (self-reported disease vs biochemical measurement of TSH and/or thyroid hormones). Albeit often used in epidemiologic studies, self-reporting is less reliable than laboratory measurements (37). Most studies report hyperthyroidism to be a risk factor for fractures $(6,7,8,9,11,12)$, and even subclinical hyperthyroidism has been associated with increased fracture risk $(13,14)$. Moreover, studies have reported increased fracture risk related to hypothyroidism $(6,10,12)$ as well as to differences in thyroid function within the reference range $(13,17,18)$. However, especially outside the hyperthyroid range, no relation between levels of thyroid function and fracture risk has also frequently been reported $(7,13$, $14,20)$, and there is even one study where self-reported previous hyperthyroidism appeared to decrease foot fracture risk (19).
Treatment for thyroid dysfunction has been reported to reduce fracture risk $(10,12)$. Subjects with indications of pathological thyroid function in HUNT2 were recommended to consult their GP. At the time of HUNT2, many experts advocated liberal treatment of subclinical thyroid dysfunction (38), so most participants with overt and many with subclinical thyroid dysfunction were probably put on treatment shortly after HUNT2. This is different from most studies discussed above. Our results could indicate that at least thyroid dysfunction that is recognised and treated should be of minor importance for fracture risk.

To our knowledge, no previous study has examined the role of TPOAb status on the association between thyroid function and fracture risk. However, recent studies have reported TRAb to have an effect on bone independent of TSH and thyroid hormones $(21,22)$. This raises the hypothesis that the aetiology of thyroid dysfunction may be of importance for bone health, but it needs confirmation in other studies.

In conclusion, our results showed no statistically significant relation between baseline TSH and fracture hazard during a mean follow-up of 12.5 years, albeit the data hinted a slightly increased hip fracture risk among women with low and high TSH. For patients with thyroid dysfunction, increased risk of non-vertebral fractures should be of limited concern as long as the dysfunction is followed up and treated according to updated guidelines.

\section{Declaration of interest}

The authors declare that there is no conflict of interest that could be perceived as prejudicing the impartiality of the research reported.

\section{Funding}

A Svare has received grants from Norwegian Extra Foundation for Health 2009-2011, and a grant from the Rehabilitation and the Liason committee Central Norway Regional Health Autority-NTNU in 2012.

\section{Author contribution statement}

A Svare designed the study, performed the analyses, interpreted the results and wrote the article. T I L Nilsen gave statistical advice, interpreted the results and wrote the article. S Forsmo, B O Åsvold and B Schei interpreted the results and wrote the article. T Bjøro was responsible for the laboratory tests, interpreted the results and wrote the article. A Langhammer designed the study, interpreted the results and wrote the article.

\section{References}

1 Bjøro T, Holmen J, Kruger O, Midthjell K, Hunstad K, Schreiner T, Sandnes L \& Brochmann H. Prevalence of thyroid disease, thyroid dysfunction and thyroid peroxidase antibodies in a large, unselected population. The Health Study of Nord-Trondelag (HUNT). European Journal of Endocrinology 2000143 639-647. (doi:10.1530/eje.0.1430639) 
2 Boelaert K \& Franklyn JA. Thyroid hormone in health and disease. Journal of Endocrinology $2005 \mathbf{1 8 7}$ 1-15. (doi:10.1677/joe.1. 06131)

3 Cooper DS \& Biondi B. Subclinical thyroid disease. Lancet 2012 379 1142-1154. (doi:10.1016/S0140-6736(11)60276-6)

4 Barrett-Connor E, Weiss TW, McHorney CA, Miller PD \& Siris ES. Predictors of falls among postmenopausal women: results from the National Osteoporosis Risk Assessment (NORA). Osteoporosis International 200920 715-722. (doi:10.1007/s00198-0080748-2)

5 von Recklinghausen FD. Die fibröse oder deformierende Ostitis, die Osteomalazie und die osteoplastische Karzinose in ihren gegenseitigen Beziehungen. Festschrift R. Virchow, pp 1-89. Berlin: Georg Reimer Verlag, 1891.

6 Ahmed LA, Schirmer H, Berntsen GK, Fonnebo V \& Joakimsen RM. Self-reported diseases and the risk of non-vertebral fractures: the Tromso study. Osteoporosis International 200617 46-53. (doi:10.1007/s00198-005-1892-6)

7 Bauer DC, Ettinger B, Nevitt MC \& Stone KL. Risk for fracture in women with low serum levels of thyroid-stimulating hormone. Annals of Internal Medicine 2001134 561-568. (doi:10.7326/ 0003-4819-134-7-200104030-00009)

8 Cummings SR, Nevitt MC, Browner WS, Stone K, Fox KM, Ensrud KE, Cauley J, Black D \& Vogt TM. Risk factors for hip fracture in white women. New England Journal of Medicine 1995332 767-773. (doi:10.1056/NEJM199503 233321202)

9 Gallagher JC, Melton LJ \& Riggs BL. Examination of prevalence rates of possible risk factors in a population with a fracture of the proximal femur. Clinical Orthopaedics and Related Research 1980 $153158-165$.

10 Vestergaard P, Weeke J, Hoeck HC, Nielsen HK, Rungby J, Rejnmark L, Laurberg P \& Mosekilde L. Fractures in patients with primary idiopathic hypothyroidism. Thyroid $200010335-$ 340. (doi:10.1089/thy.2000.10.335)

11 Vestergaard P, Rejnmark L, Weeke J \& Mosekilde L. Fracture risk in patients treated for hyperthyroidism. Thyroid 200010 341-348. (doi:10.1089/thy.2000.10.341)

12 Vestergaard P, Rejnmark L \& Mosekilde L. Influence of hyper- and hypothyroidism, and the effects of treatment with antithyroid drugs and levothyroxine on fracture risk. Calcified Tissue International 200577 139-144. (doi:10.1007/s00223-0050068-x)

13 Waring AC, Harrison S, Fink HA, Samuels MH, Cawthon PM, Zmuda JM, Orwoll ES \& Bauer DC. A prospective study of thyroid function, bone loss, and fractures in older men: the MrOS study. Journal of Bone and Mineral Research 201328 472-479. (doi:10.1002/jbmr.1774)

14 Wejda B, Hintze G, Katschinski B, Olbricht T \& Benker G. Hip fractures and the thyroid: a case-control study. Journal of Internal Medicine 1995237 241-247. (doi:10.1111/j.1365-2796.1995. tb01172.x)

15 Lee JS, Buzkova P, Fink HA, Vu J, Carbone L, Chen Z, Cauley J, Bauer DC, Cappola AR \& Robbins J. Subclinical thyroid dysfunction and incident hip fracture in older adults. Archives of Internal Medicine 2010170 1876-1883. (doi:10.1001/archinternmed.2010.424)

16 Vadiveloo T, Donnan PT, Cochrane L \& Leese GP. The Thyroid Epidemiology, Audit, and Research Study (TEARS): morbidity in patients with endogenous subclinical hyperthyroidism. Journal of Clinical Endocrinology and Metabolism 201196 1344-1351. (doi:10.1210/jc.2010-2693)

17 Mazziotti G, Porcelli T, Patelli I, Vescovi PP \& Giustina A. Serum TSH values and risk of vertebral fractures in euthyroid post-menopausal women with low bone mineral density. Bone 201046 747-751. (doi:10.1016/j.bone.2009.10.031)

18 Murphy E, Gluer CC, Reid DM, Felsenberg D, Roux C, Eastell R \& Williams GR. Thyroid function within the upper normal range is associated with reduced bone mineral density and an increased risk of nonvertebral fractures in healthy euthyroid postmenopausal women. Journal of Clinical Endocrinology and Metabolism 201095 3173-3181. (doi:10.1210/jc.20092630)

19 Seeley DG, Kelsey J, Jergas M \& Nevitt MC. Predictors of ankle and foot fractures in older women. The Study of Osteoporotic Fractures Research Group. Journal of Bone and Mineral Research 199611 1347-1355. (doi:10.1002/jbmr. 5650110920)

20 van der Deure WM, Uitterlinden AG, Hofman A, Rivadeneira F, Pols HA, Peeters RP \& Visser TJ. Effects of serum TSH and $\mathrm{FT}_{4}$ levels and the TSHR-Asp727Glu polymorphism on bone: the Rotterdam Study. Clinical Endocrinology 200868 75-81. (doi:10.1111/j.1365-2265.2007.03016.x)

21 Belsing TZ, Tofteng C, Langdahl BL, Charles P \& FeldtRasmussen U. Can bone loss be reversed by antithyroid drug therapy in premenopausal women with Graves' disease? Nutrition E Metabolism 20107 72. (doi:10.1186/1743-7075-7-72)

22 Majima T, Komatsu Y, Doi K, Takagi C, Shigemoto M, Fukao A, Morimoto T, Corners J \& Nakao K. Negative correlation between bone mineral density and TSH receptor antibodies in male patients with untreated Graves' disease. Osteoporosis International $2006 \mathbf{1 7} 1103-1110$. (doi:10.1007/ s00198-006-0091-4)

23 Holmen J, Midthjell K, Krüger Ø, Langhammer A, Holmen TL, Bratberg GH, Vatten L \& Lund-Larsen PG. The Nord-Trøndelag Health Study 1995-97 (HUNT 2): objectives, contents and participation. Norsk Epidemiologi 200313 19-32.

24 Surks MI, Goswami G \& Daniels GH. The thyrotropin reference range should remain unchanged. Journal of Clinical Endocrinology and Metabolism 200590 5489-5496. (doi:10.1210/ jc.2005-0170)

25 Diez JJ \& Iglesias P. Spontaneous subclinical hypothyroidism in patients older than 55 years: an analysis of natural course and risk factors for the development of overt thyroid failure. Journal of Clinical Endocrinology and Metabolism 200489 4890-4897. (doi:10.1210/jc.2003-032061)

26 Parle JV, Franklyn JA, Cross KW, Jones SC \& Sheppard MC. Prevalence and follow-up of abnormal thyrotrophin (TSH) concentrations in the elderly in the United Kingdom. Clinical Endocrinology 199134 77-83. (doi:10.1111/j.1365-2265.1991. tb01739.x)

27 Diamantopoulos AP, Rohde G, Johnsrud I, Skoie IM, Hochberg M \& Haugeberg G. The epidemiology of low- and high-energy distal radius fracture in middle-aged and elderly men and women in Southern Norway. PLOS ONE 20127 e43367. (doi:10.1371/ journal.pone.0043367)

28 Rothman KJ, Greenland S \& Lash TL. Validity in epidemiologic studies. In Modern Epidemiology, 3rd edn, ch 9, pp 128-147. Eds Rothman KJ, Greenland S \& Lash TL. Philadelphia: Lippincott Williams \& Wilkins, 2008.

29 El Hadidy el HM, Ghonaim M, El Gawad SS \& El Atta MA. Impact of severity, duration, and etiology of hyperthyroidism on bone turnover markers and bone mineral density in men. BMC Endocrine Disorders 201111 15. (doi:10.1186/1472-682311-15)

30 Udayakumar N, Chandrasekaran M, Rasheed MH, Suresh RV \& Sivaprakash S. Evaluation of bone mineral density in thyrotoxicosis. Singapore Medical Journal 2006 47 947-950.

31 Svare A, Nilsen TI, Bjoro T, Forsmo S, Schei B \& Langhammer A. Hyperthyroid levels of TSH correlate with low bone mineral density: the HUNT 2 study. European Journal of Endocrinology 2009 161 779-786. (doi:10.1530/EJE-09-0139)

32 Kim BJ, Lee SH, Bae SJ, Kim HK, Choe JW, Kim HY, Koh JM \& Kim GS. The association between serum thyrotropin (TSH) levels and bone mineral density in healthy euthyroid men. Clinical Endocrinology 201073 396-403. (doi:10.1111/j.1365-2265. 2010.03818.x)

33 Kim DJ, Khang YH, Koh JM, Shong YK \& Kim GS. Low normal TSH levels are associated with low bone mineral density in healthy postmenopausal women. Clinical Endocrinology 2006 64 86-90. (doi:10.1111/j.1365-2265.2005.02422.x) 
34 Morris MS. The association between serum thyroid-stimulating hormone in its reference range and bone status in postmenopausal American women. Bone 200740 1128-1134. (doi:10.1016/j. bone.2006.12.001)

35 Grimnes G, Emaus N, Joakimsen RM, Figenschau Y \& Jorde R. The relationship between serum TSH and bone mineral density in men and postmenopausal women: the Tromso study. Thyroid 200818 1147-1155. (doi:10.1089/thy.2008.0158)

36 Lee WY, Oh KW, Rhee EJ, Jung CH, Kim SW, Yun EJ, Tae HJ, Baek KH, Kang MI, Choi MG et al. Relationship between subclinical thyroid dysfunction and femoral neck bone mineral density in women. Archives of Medical Research 200637 511-516. (doi:10.1016/j.arcmed.2005.09.009)
37 Oksanen T, Kivimaki M, Pentti J, Virtanen M, Klaukka T \& Vahtera J. Self-report as an indicator of incident disease. Annals of Epidemiology 201020 547-554. (doi:10.1016/j.annepidem. 2010.03.017)

38 Surks MI \& Ocampo E. Subclinical thyroid disease. American Journal of Medicine $1996 \mathbf{1 0 0 ~ 2 1 7 - 2 2 3 . ~ ( d o i : 1 0 . 1 0 1 6 / S O 0 0 2 - ~}$ 9343(97)89462-4)

Received 1 July 2013

Revised version received 7 September 2013

Accepted 12 September 2013 